\title{
The Role of Interpersonal Communication Between Teachers and High School's Students in Overcome Bullying Behavior
}

\author{
Mardhiyyah1, Ghazaly Ama La Nora 2, MA. Theresa Bringas Nardo³ \\ 1,2Fakultas Ilmu Komunikasi, Universitas Mercu Buana, Jakarta \\ 3 Tarlac Agricultural University, Philippines \\ E-mail: mardhiyyah@mercubuana.ac.id
}

\begin{abstract}
Abstrak
Bullying adalah perilaku atau tindakan agresif yang melibatkan ketidakseimbangan kekuatan yang merugikan orang lain. Sebagian besar bullying terjadi di sekolah dan banyak data yang dapat membuktikan bahwa sekolah adalah penyumbang terbesar perilaku bullying. Luaran dari pengabdian kepada masyarakat ini adalah Mampu memberikan pemahaman tentang pentingnya menciptakan kondisi dan suasana sekolah yang baik dan nyaman bagi siswa agar terhindar dari perilaku bullying di sekolah. Pengabdian kepada masyarakat ini dilaksanakan dengan metode ceramah disertai penjelasan dan diskusi interaktif yang melibatkan seluruh peserta. Pelaksanaan Pengabdian kepada Masyarakat ini berjalan dengan baik dan lancar. Faktor keberhasilan kegiatan Pengabdian Masyarakat di MAN 10 Jakarta ini adalah antusiasme peserta dalam menerima materi dan penyampaian materi yang komunikatif oleh para narasumber. Sedangkan kendala dalam kegiatan ini adalah belum tersedianya narasumber yang kredibel dan terbatasnya waktu untuk melaksanakan kegiatan.
\end{abstract}

Kata Kunci: Komunikasi interpersonal, SMA, Perundungan

\begin{abstract}
Bullying is aggressive behavior or action that involves an imbalance of power that is detrimental to others. Most bullying occurs at school and a lot of data can prove that schools are the biggest contributors to bullying behavior. The output of this community services is being able to provide an understanding of the importance of creating conditions and a good and comfortable school atmosphere for students to avoid bullying behavior at school. This community services held with lecture method accompanied by an explanation and interactive discussion involving all participants. The implementation of this Community Service is going well and smoothly. The success factor of this Community Service activities at MAN 10 Jakarta is the enthusiasm of participants in receiving material and communicative material delivery by the Speakers. While the obstacle in this activity is the unavailability of credible resource persons and the limited time to carry out the Activity.
\end{abstract}

Keywords: Interpersonal Communication, High School, Bullying

\section{Introductions}

Generally, bullying is recognized as aggressive, repeated, intentional behavior involving an imbalance of power aimed toward an individual or group of individuals who cannot easily defend themselves (O'brien, 2019). This aggressive behavior can be done repeatedly and causes serious problems in the bullied. Based on the official website of Stop Bullying United States, actions categorized as harassment are aggressive and contain an imbalance of strength and repetition. This power imbalance is defined as people who use their strengths such as physical strength, embarrassing access to information, or 
popularity to control or harm others.

There are many types of bullying that children and adults can experience. There are Physical Bullying, Verbal Bullying, Emotional Intimidation, Racist Bullying, Sexual Bullying, and Cyberbullying (https://www.stompoutbullying.org/, 2019). Physical Bullying is the most obvious form of intimidation and can consist of kicking, hitting, biting, pinching, hair pulling, and making threats. A bully may threaten to punch you if you don't give up your money, your lunch, etc. Verbal Bullying often accompanies physical behavior. This can include name calling, spreading rumors, and persistent teasing. Emotional Intimidation is closely related to these two types of bullying. A bully may deliberately exclude you from a group activity such as a party or school outing. Racist Bullying can take many forms: making racial slurs, spray painting graffiti, mocking the victim's cultural customs, and making offensive gestures. Sexual bullying is unwanted physical contact or abusive comments. Cyberbullying is one or a group of kids or teens using electronic means via computers and mobile phones (emails, Web sites, chat rooms, instant messaging and texting) to torment, threaten, harass, humiliate, embarrass or target another kid or teen.

Cyberbullying or harassment in cyberspace. Harassment in cyberspace is a bullying behavior carried out using digital technology. This bullying in cyberspace includes uploading inappropriate images or videos, spreading gossip online, and using other people's information on social media. Fifth, Sexual Bullying. Quoted from Very Well Family, sexual bullying is a dangerous and sexually embarrassing act. Sexual intimidation includes calling on sexual or cat-calling names, vulgar gestures, touching and pornographic material(Gracivia et al., 2019) .

At this time, many people have recorded the phenomenon of cyberbullying because of the proliferation of cases raised by the media(Nugraheni, 2021). Moreover, many times he made apologies and sentiments with the police, not making ZG run away from blasphemy on his social media accounts. It started elementary school in April 2016. The elementary school shouted at the female police officer and claimed to be the son of the general when he got the ticket. Conversely, the same is true for Instagram celebrities or crews, who are on social media every month in mid-2016 because of posts raised for 19year-olds, such as wearing clothes, smoking, drinking, romanticism with lovers, and choices of harsh words. In this case, mass media in the form of print and electronic media as a means of communication and information, both at the local and national levels (Kurniawan Akbar, 2012).

The reality in cyberspace is a different reality compared to reality in the real world, even though messages from communication are almost the same, that is, messages sent to the recipient of the message. Messages have various meanings depending on the situation and conditions. Communication carried out through a computer is a process of communication carried out using a computer that involves many people for certain purposes(Rulli Nasrullah, 2015)

Bullying behavior is currently the most widely practiced by students. Examples 
include mocking, mocking, and even encouraging, hitting and using other acts of violence. For the perpetrators of bullying, things like that are pleasing to him and can satisfy his feelings, and as a form of indicating the existence that he has power in school. But for victims, bullying behavior is very unpleasant and disturbs their lives, not only life in school but also in life outside of school. It is also possible that the victim will be traumatized by the bullying he received so that there is a reluctance to return to school.

Although bullying behaviors were a primary consideration of young people's understanding of bullying, many considered the consequences associated with bullying and in particular, the impact on mental health. In these examples, the specifics of the bullying event were irrelevant to young people and the focus was on how the behavior was received by the recipient (O'brien, 2019).

In other cases, schools are less affordable places for parents to supervise. So that students feel it will be more free to carry out bullying behavior without fearing that their behavior will be known by their parents. Most bullying behavior is done by older students and is done to younger classmates or students who are younger than the perpetrators, or better known as seniority. The seniors feel that they hold power in the school and the juniors must respect them. They will carry out this bullying with the excuse that their juniors must also feel what they once felt from their seniors. They do the bullying to younger classmates who are considered weak and cannot fight their behavior, because they also know that the victim will not report the behavior to the teacher.

KPAI found that the number of children who were victims of bullying in the school environment was (87.6\%). Of the figures (87.6\%), $(29.9 \%)$ cases of bullying were committed by teachers, (42.1\%) were committed by classmates, and $(28.0 \%)$ were carried out by other classmates (Erika et al., 2017). The above data can prove that schools are the biggest contributors to bullying behavior.

A lot of researches do on the crime of cyberbullying in Indonesia. For example research on abuse among elementary school students (Rulli Nasrullah, 2015). Cyberbullying crimes can do to children and also adults reviewed(Triantoro Safaria, 2015). The crime of cyberbullying does not only occur in Indonesia, but also in other countries(Haryati, 2014). Notwithstanding, research on the forms of cyberbullying and its handling widely studied. However, research on the crime of cyberbullying and its prevention can found widely. The existence of harassment events, developments in the world of technology and gadgets can give birth to new social media. Although social media has developed, it can have a negative impact, one of which is cyber violence. This factor makes cyberbullying crime relatively safe and easy to do by irresponsible parties.

Education and the provision of appropriate educational methods is a powerful way to develop a child's personality for the better. Surely this is not an easy thing to do. Development of children's character to be able to behave as well as possible, is something that is certainly expected by everyone, especially parents. Things that must be considered in educating and providing the most appropriate educational methods to be captured by children, must also pay attention to the value of communication. Communication within a 
group so that it can learn effectively, becomes very important. Ideas, knowledge, and opinions must be conveyed properly so that the process of providing information in it can be captured properly. Communication in organizations involving two people or better known as interpersonal communication skills. Based on research conducted by Robbins and Hunsaker (Matin et al., 2010), interpersonal communication consists of three dimensions which have their own components.

Interpersonal communication is a form of communication made verbally through words, non-verbal through expression, body language, even in the form of silence (Koide, 2003). The dimensions of interpersonal communication according to Robbins and Hunsaker are the presence of leadership, the process of communication, and motivation. These three dimensions involve the role of a person to be able to balance these three things so that the information provided can be conveyed as well as possible. Returning to the appropriate educational methods to be given to children, effective interpersonal communication is needed so that every learning to children in building good character can be achieved.

Cyberbullying is not only an individual problem. It is clearly dependent on social constellations, as it always includes perpetrators and victims who are embedded in larger social structures and environments. This sociostructural character is most relevant for the discussion of cyberbullyingwith reference to children and adolescents. As they pass through various phases of personality development, the social context is essential. Early social development research has stressed the need to analyze social references in addition to individual aspects(Festl \& Quandt, 2013)

Seeing the phenomenon of these problems in Indonesian children, it is necessary to have a fundamental transformation in the system that can educate children for the better, one of them is through the interpersonal communication approach that teachers do in schools. The form of methods that really provide a space to share stories, creativity for children. Teachers can also be a motivator in increasing children's competence, so that children do not behave wrongly in finding their true identity.

According to previous research about Cyberbullying at school, the teachers are concerned about the impact of cyber-bullying; they assume that bullying and violence online are a severe problem at school. The context of cyber-bullying intimidation can have a broad impact because of the ease of access to information through internet technologyanyone, whenever and wherever data can be accessed openly. Cyber-bullying can have a more severe impact on mental health problems and academic problems than traditional bullying(Nhung et al., 2020).

Cyber-bullying must receive serious attention from school stakeholders. Teachers, parents, and peers must play a role in reducing cyber-bullying. Various protective programs can be carried out for the prevention of cyberbullying, and education is a crucial component for the prevention and intervention in cyber-bullying. Educators need to develop creative strategies to engage young people about the use of accessible technology in a meaningful way. In this context, educators can create lessons that teach students to 
post their opinions appropriately on internet media. A conducive school environment has a vital role in reducing the occurrence of cyber-bullying(Nhung et al., 2020).

Cyber-bullying is caused by factors in the school environment, family, teachers, friendship, and personal factors. The effects of cyber-bullying include psychological effects (depression, anxiety, loneliness, anger, social isolation), reactive behavior (suicide, violence), academic problems, and social difficulties. Meanwhile, protective measures to reduce the occurrence of cyber-bullying include the involvement of school, family, peers, and individuals. The problem of cyber-bullying is serious both at school, and outside of school, therefore it needs serious attention by all stakeholders to deal with cyber-bullying issues(Nhung et al., 2020).

This makes the process of providing education and building the character of children in schools not optimal. Children tend to go to school only as a fulfillment of their duties as a student, and instead do activities that are not good in interacting with their friends, one of which is bullying. Though these children should be expected to have a high enthusiasm to be active in school, show the best behavior possible, and foster their love for themselves as students and others who also have the same rights as them. Therefore, the need for interpersonal communication that must be done by teachers in schools so that children are more comfortable to learn and actively participate in doing every activity and socialize in school properly. Therefore, this service is important to do.

\section{Method}

This community service uses the lecture method accompanied by an explanation and interactive discussion involving all participants. This lecture method is used with the intention that participants understand the role of interpersonal communication between teacher and student in avoiding bullying behavior at school.

The steps used in implementing this service program are as follows : Participants are given material about the dangers of bullying behavior ; Participants are given a description of cases that have occurred in connection with the dangers of bullying in schools; Participants are given an explanation of the role of interpersonal communication between teacher and student to avoid bullying behavior at school. 


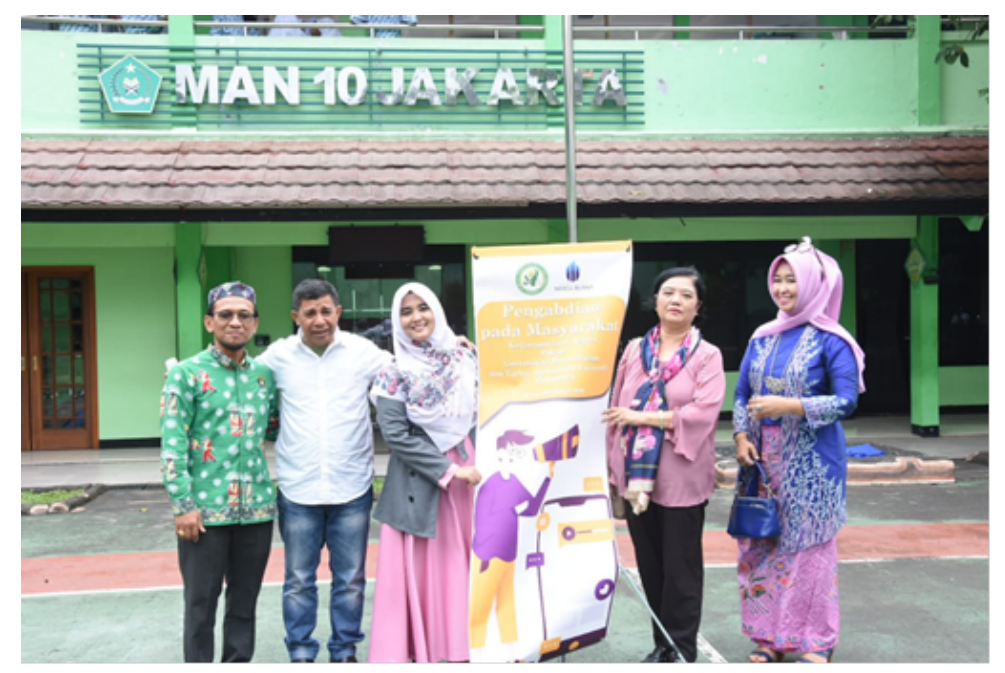

Picture 1. Implementer Team and Teacher of MAN 10 Jakarta

Evaluation is carried out during the activity process, through observing the course of the extension activities. At the material delivery stage, the evaluation is done by concluding the participants' understanding and seeing the activity of asking questions. The results of counseling are measured by the accuracy of participants in answering questions about the role of interpersonal communication between teachers and students to avoid bullying behavior in schools.

\section{Result and Discussion}

\section{Result}

The implementation of Community Service Activities on the Role of Interpersonal Communication between Teachers and High School Students in dealing with bully behavior is going well and smoothly. This activity was carried out on Thursday, February 20, 2020 at Madrasah Aliyah Negeri 10 Jakarta. This activity was attended by 31 participants who were students of MAN 10 Jakarta. Community Service Activities on the Role of Interpersonal Communication between Teachers and High School Students in responding to bullying behavior in Madrasah Aliyah Negeri 10 Jakarta is carried out in several stages, namely:

(1) Submission of Material

In this stage, the activity organizer gives material in the form of presentations to participants. The material presented is an explanation of the phenomenon of rampant bullying behavior in schools, explains the importance of interpersonal communication between teachers and students to overcome bully behavior, and the importance of building good and pleasant situations and conditions in schools to avoid bullying behavior. Submission of material is supported by presentations using infocus and some video footage about bullying behavior at school. At this stage, participants are able to receive information and direction well and smoothly.

(2) Question and Answer / Interactive Discussion

After delivering the material about the Role of Interpersonal Communication 
between Teachers and High School Students in responding to bullying behavior, participants were given the opportunity to ask questions about the material that had been presented previously. This question and answer session were divided into 1 question session with 5 questioners.

Implementation of Community Service on the Role of Interpersonal Communication between Teachers and High School Students in responding to bullying behavior at MAN 10 Jakarta is very positive and leaves a deep impression on the implementers and participants of the activity. This is because, community service activities are carried out, such as being a pleasant active discussion. This can be seen from the active participants during the question and answer / interactive discussion with the implementer.

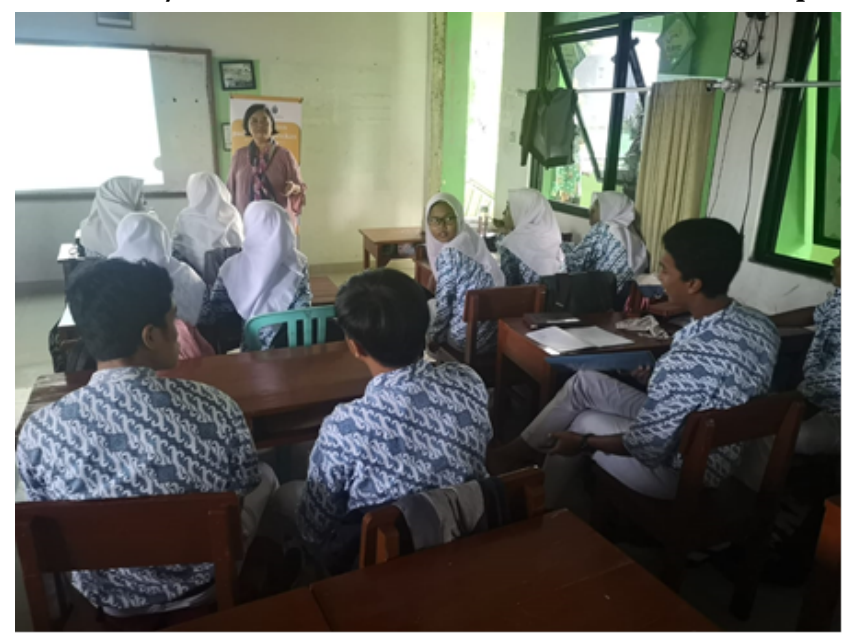

\section{Discussion}

Picture 2. The view of community service implementation

The success of community service regarding the role of interpersonal communication between teachers and high school students in responding to bullying behavior at MAN 10 Jakarta is influenced by several factors, namely:

1. Enthusiasm of Participants with the material presented

The issue of the role of interpersonal communication between teachers and high school students in dealing with bully behavior is the basis for the emergence of high enthusiasm from the participants. The material delivered by the implementers was able to provide other insights for participants, because bullying behavior often occurs in schools and becomes a habit that is very difficult to break. Bullying is not always caused by physical, sometimes also caused by economic and cultural factors.

2. How to deliver communicative material by the Speaker.

The communicative method of delivering material was also a success factor of this activity. The material presented is also equipped with a video, which explains the dangers of bully behavior at school. 


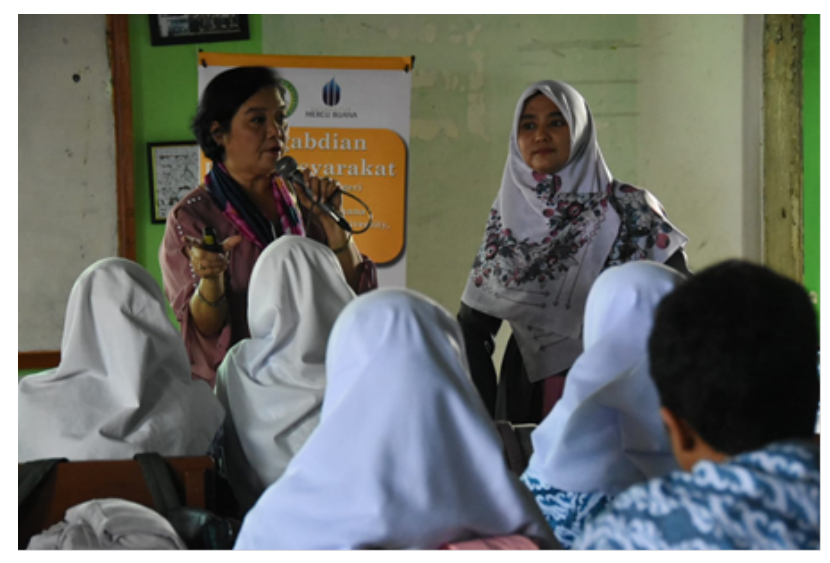

Picture 3. The speaker explained the materials of interpersonal communication

As for the obstacles in Community Service activities regarding the role of interpersonal communication between teachers and high school students in responding to bullying behavior at MAN 10 Jakarta are as follows: (1) The unavailability of more credible sources, The absence of credible speakers in delivering the material is an inhibiting factor in this activity. Especially after seeing that participants were very enthusiastic in discussing the role of interpersonal communication between teachers and high school students in responding to bully behavior. Organizers should also invite related parties such as psychologists, so that the material presented will be more diverse and complete. As a result, the questions are answered 'improvise' according to the knowledge of the implementer of the activity; (2) Limited time to carry out the Activities, the Community Service Activities that discuss the Role of Interpersonal Communication between Teachers and High School Students in addressing bully behavior at MAN 10 Jakarta generates active and positive discussions. The activity was filled with materials and evaluation of activities carried out with question and answer sessions which generated great enthusiasm from the participants. This then causes the implementation time of 1 (one) hour to be short and insufficient.

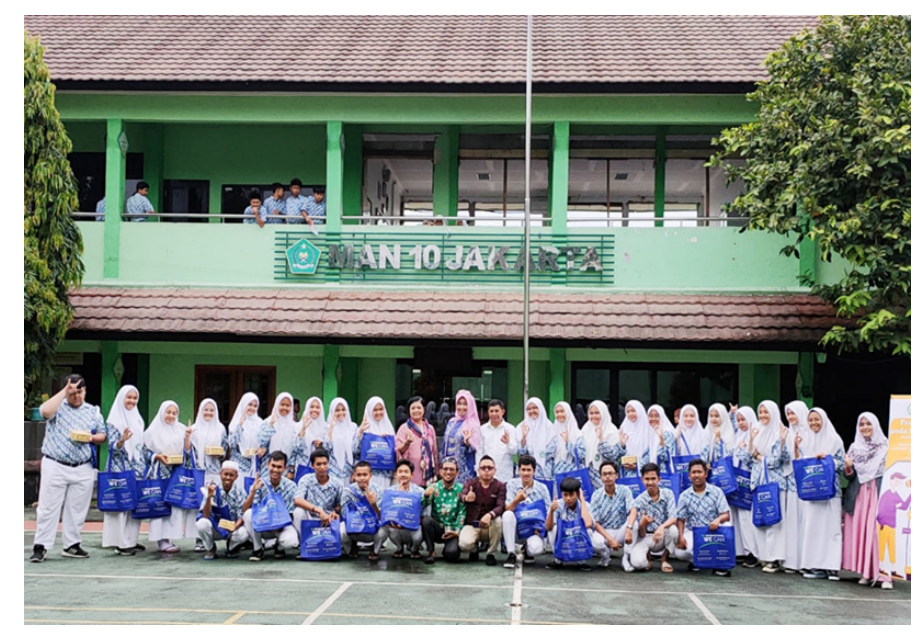

Picture 4. The Implementer Team and students of MAN 10 Jakarta 


\section{Conclusion}

Based on the discussion above, it can be concluded that the success factor of Community Service activities that discusses the Role of Interpersonal Communication between Teachers and High School Students to avoid bullying behavior at MAN 10 Jakarta is the enthusiasm of participants in receiving material and communicative material delivery by the Speakers. While the obstacle in this activity is the unavailability of credible resource persons and the limited time to carry out the activity. To ensure the smoothness of Community Service activities that discuss the Role of Interpersonal Communication between Teachers and High School Students to avoid this bully behavior going forward, there are a few notes as follows: (1) Bring in appropriate and credible resource persons in the implementation of training activities; (2) Provides a slightly longer time to implement the activity (according to the conditions and enthusiasm of the activity participants; (3) Increasing and increasing the number of achievement outcomes so that they can be more beneficial to the community.

\section{Reference}

Erika, K. A., Pertiwi, D. A., \& Seniwati, T. (2017). Bullying Behaviour of Adolescents Based on Gender, Gang and Family. Jurnal Ners, 12(1), 126. https://doi.org/10.20473/jn.v12i1.4396

Festl, R., \& Quandt, T. (2013). Social Relations and Cyberbullying: The Influence of Individual and Structural Attributes on Victimization and Perpetration via the Internet. Human Communication Research, 39(1), 101-126. https://doi.org/10.1111/j.1468-2958.2012.01442.x

Gracivia, L., Https://www.cnnindonesia.com/gaya-hidup/20190411135109-260385320/mengenal-jenis-jenis-bullying-atau-perundungan., B. artikel C. I. "Mengenal J. B. atau P. selengkapnya di sini:, \& Https://app.cnnindonesia.com/, D. A. C. I. sekarang. (2019). Mengenal Jenis-jenis Bullying atau Perundungan Baca artikel CNN Indonesia "Mengenal Jenis-jenis Bullying atau Perundungan" selengkapnya di sini: https://www.cnnindonesia.com/gaya-hidup/20190411135109-260-

385320/mengenal-jenis-jenis-bullying-atau-perundung.

Https://Www.Cnnindonesia.Com/.

Haryati. (2014). Cyberbullying Side Lain Dampak Negatif dari Internet. Mediakom, Vol. 11. https://www.stompoutbullying.org/. (2019). Forms of Bullying. Https://Www.Stompoutbullying.Org/.

Koide, G. (2003). Verbal and non-verbal communication. Trends in the Sciences, 8(3), 2831. https://doi.org/10.5363/tits.8.3_28

Kurniawan Akbar. (2012). Pengaruh Media Massa terhadap Proses Peradilan Pidana dalam Kasus Pencurian Kakao oleh Minah. Unnes Law Journal: Jurnal Hukum Universitas Negeri Semarang, Vol. 1(No. 1).

Matin, H. Z., Jandaghi, G., Karimi, F. H., \& Hamidizadeh, A. (2010). Relationship between interpersonal communication skills and organizational commitment (Case study: Jahad keshavarzi and university of Qom, Iran). European Journal of Social Sciences, 13(3), 387-398.

Nhung, L. N. A., Basuki, A., Mahfud, T., \& Saputro, I. N. (2020). Cyber-bullying among 
adolescent at school: A literature review. International Journal of Psychosocial Rehabilitation, 24(7), 9700-9712. https://doi.org/10.37200/IJPR/V24I7/PR270973

Nugraheni, P. D. (2021). The New Face of Cyberbullying in Indonesia: How can We Provide Justice to the Victims? The Indonesian Journal of International Clinical Legal Education, 3(1), 57-76. https://doi.org/10.15294/ijicle.v3i1.43153

O'brien, N. (2019). Understanding alternative bullying perspectives through research engagement with young people. Frontiers in Psychology, 10(AUG). https://doi.org/10.3389/fpsyg.2019.01984

Rulli Nasrullah. (2015). Cyber Bullying di Status Facebook dari Kantor Pusat Humas Mabes Polri. Jurnal ITB Sosioteknologi Vol. 14, No. 1, 14.

Triantoro Safaria. (2015). Apakah Pengalaman Spiritual Harian, Harga Diri dan Prediktor Harmony Keluarga Penindasan Cyberbaring Diantara Siswa SMA? Jurnal Internasional Studi Penelitian Di Psikologi, Vol. 4, No. 